\title{
小規模小売店の最適更新行動に関する研究 ${ }^{1}$ \\ Optimal Renewal Behavior of Small-scale Retail Shops
}

\section{奥村 誠 ${ }^{2} \cdot$ 松村憲—3 \\ Makoto OKUMURA and Ken-ichi MATSUMURA}

\section{1. 商店街の衰退と更新行動}

1992 年の大規模小売店舗法 (大店法) の改正によ る大規模店出店規制の緩和は、バブル崩壊後の消費 者の低価格指向への傾斜と相まってディスカウント ストアなどの郊外型大規模店の增加をもたらした。 その結果小規模小売店の持続は困難となり既存市街 地の商店街の衰退が加速した。94 年までの 3 年問に 従業員 4 人以下の零細小売店舗の数は約 $10 \%$ という 大きな率で減少している1)。都市の中心市街地に存 在する商店街の空洞化は地域経済の停滞を招くばか りでなく、市街地の活気を失わせ、魅力ある都市づ くりを困難にさせるという問題を引き起こす。都市 づくりの立場から見ても、小規模な商店からなる既 存商店街の活性化は重要な課題となっており2)、空 店舗の活用も含めてさまざまな取り組みが模索され ている。

これまで、商店街の衰退の原因を大規模店舗と の競争に求め、商店街の生き残りのために大規模店 の出店を中止させたり店舗規模を削隇させることが 多く試みられてきた。しかし、このような戦略は長 期的には広域的な競争力を弱めるという問題点が指 摘されており1)、積極的に大規模店の広域的な集客 力を活用して共存を図った商店街の事例も報告され ている3)。

活性化に成功した商店街に共通する特徴は、積 極的に店舗の更新や業態の見直しを行い魅力を維持 していることである。本研究では商業集積における 小売店の魅力更新行動が商店街の活性化のための重 要な要因であると考える。そこでこの更新行動を動

\footnotetext{
${ }^{1}$ KeyWords; 地域計画, 産羓立地, 計面情報

2 正会貝·工博 ·広島大学助教授. 工学部第 4 類 (建設系)

( 于 739 東広島市鏡山 1-4-1) Tel\&Fax 0824-24-7827

3 正会貝·工修· (株) 日本棇合研究所·関西事業本部

（广 542 大阪市中央区南船場 3-10-19) Tel 06-243-4655
}

学最適化問題としてモデル化し、多くの商店街で魅 力更新が進まない理由を考察するとともに、更新を 進めるための活性化方策について検討する。

\section{2. 小売店の魅力と集客力}

\section{(1) 既存の研究と本研究の立場}

小売店の経営が健全に行われるためには一定数 の顧客を獲得し一定規模の売り上げを達成すること が必要であることは言うまでもない。実務的には立 地の検討段階で顧客の購買行動に関する綿密な調査 が行われるのが通例である。土木計画の分野におい ても消費者の行動モデルを部分モデルとして内生化 した商業立地モデルに関する研究が進展し、それら を土地利用の予測や都市再開発プロジェクトの評価 に使うという試みも行われている4)。

これらの研究では大規模店と既存の商店街の小 売店との競争関係を数理的に表現しているが、两者 の共存関係はうまく表現できていない。また人口、 交通条件などの外部条件と、小売店の位置や規模と いう量的な魅力の分析にとどまり、消費者のニーズ に応した売場の構成や商品の品揃え、消費者が買物 を楽しめる外装、内装の美しさ・新しさなどの質的 な鬼力についてはほとんど分析されていない。

本研究ではこれらの質的な魅力の重要性に着目 する。立地場所や小売店の規模などの量的な魅力は 立地時点において形成されると長期にわたって（建 物が老朽化して使用不可能となるまで）効力を発揮 寸るのに対して、質的な魅力は常に新たな投資を行 うことにより更新していかなけ机ば維持することが できない。立地場所や小売店の規模が同じであって も、その後適切な投資を行い質的な魅力を更新して いる場合とそうでない場合とでは、集客力には大き な差が現れてくる。大規模店との共生に成功した商 
店街は、大規模店の立地に合わせて質的な魅力の更 新を進めた商店街であることが多い3)。

本研究では小売店の位置や規模といった量的な 条件は既存の商業立地モデルによる分析にゆだねる こととし、これらの量的な条件を所与とした上で、 立地後の各小売店の質的な魅力の更新行動をモデル 化する。

新古典派の投資理論では、企業の投資行動を将 来にわたるネットのキャッシュフローの現在価値の 最適化問題としてとらえる5)6)。Jorgenson は各時点 ごとに成立すべき静学的な均衡条件をもとに均衡資 本量を求め、ついで現時点での資本量と均衡資本量 とを埋める形で投資が行なわれると考え投資関数を 提案したが、Haavelmoらにより資本調達が自由に できる完全競争企業の場合には、瞬間的な投資によ り一気に均衡資本量を達成することが最適であり、 Jorgenson 型の投資行動は見られないことが指摘さ れた。しかし Eisner らは投資に調整費用を必要とす る場合には、瞬間的な投資は最適ではなく、時間と ともに徐々に投資を行なう解が最適になることを示 した7)。本研究では、この調整費用付きの投資問題 の枠組みに沿ったモデルを用いて、小売業の魅力更 新行動を分析する。

\section{（2）小売店の質的魅力}

質的魅力の向上は、消費者のニーズや流行の変 化に対応して売場の構成を変えるというように、あ る時点で新たに投資を行うことにより達成されると 考える。「老舗」と呼ばれるように商品や店潇えを古 いままにしておくことが魅力を生む場合もあるが、 その場合でも現在のニーズにあった商品を選択的に 残したり、古い物の良さを残した新製品を開発した り、古さを際だたせるような広告やメンテナンスが 必要であり、それらを「更新投資」と考えることが できる。

このようなフローとしての魅力の増加の効果は、 投資からの時間の経過とともに減衰する。そこであ る時点での小売店の質的魅力は過去に行われた更新 行動の蓄積であると考えられる。すなわち $y_{i}(\tau)$ を $\tau$ 期に追加された質的魅力、 $\gamma$ を魅力の陳腐化率とす れば、 $t$ 期に㧍ける商店 $i$ の質的魅力 $Y_{i}(t)$ は次式に
より表現できる。

$$
Y_{i}(t)=\int_{0}^{t} y_{i}(\tau) \exp \{-\gamma(t-\tau)\} d \tau
$$

あるいは、微分型で表現すれば、

$$
\frac{\mathrm{d} Y_{i}}{\mathrm{~d} t}=y_{i}(t)-\gamma Y_{i}(t)
$$

となる。

\section{（3）消費者の意思決定}

消費者は買物に当たり 2 段階の意思決定を行う と仮定する4)。まず、消費者は買物行動を行う前に、 複数の商業集積の量的条件と集積全体としての質的 魅力を考慮して、どの商業集積を訪れるべきかを選 択する。ついでその商業集積に来訪して、集積内の 各小売店の規模や質的魅力を勘案し、その小売店で の賆入額をいくらにするかを決定すると仮定する。 本研究では量的条件は所与としているから、集積全 体での集客力 $f や$ 集積の集客 1 人当たりの各小売店 の粗利益 $g$ は集積全体の質的魅力 $Y_{0}$ と各小売店の質 的魅力 $Y_{i}$ に依存する。

\section{3. 小売店の最適更新行動のモデル化}

\section{（1） 小売店の予想形成}

各小売店は、上記のような消費者の行動パター ンを熟知しているとしょう。今後自店の魅力更新を 計画する際には、自店のそれまでの更新行動を顧み るとともに、集積内の他の小売店がそれまでに行っ た投资、さらに他店が今後行うであろう投資を考慮 して意思決定する必要がある。そこで他店の将来の 行動については何らかの予測を行うものとする。商 業集皘内の他店が有する質的魅力の平均的な水準の 予測值を $\widetilde{Y_{0}(t)}$ とする。このとき将来時点 $t$ における 利閏 $\pi は$ 次式のように予測さ机るであろう。

$$
\begin{aligned}
& \pi_{i}\left(Y_{i}(t), y_{i}(t), \widetilde{Y_{o}(t)}\right) \\
& =f\left(Y_{i}(t), \widetilde{Y_{o}(t)}\right) g\left(Y_{i}(t), \widetilde{Y_{o}(t)}\right) \\
& \quad-C\left(y_{i}(t), Y_{i}(t)\right)
\end{aligned}
$$

ここに $f$ は集積の集客数を表わし $Y_{i}(t)$ と $\widetilde{Y_{o}(t)}$ に対す る增加関数である。 $g$ は集積の集客 1 人が当該小売店

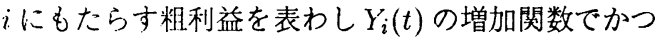

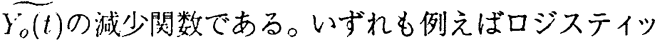
ク関数を仮定寸ることができる。 $C(y, Y)$ は質的な魅 力が $Y_{i}(t)$ である時、 $y_{i}(t)$ を付加するために必要な更 


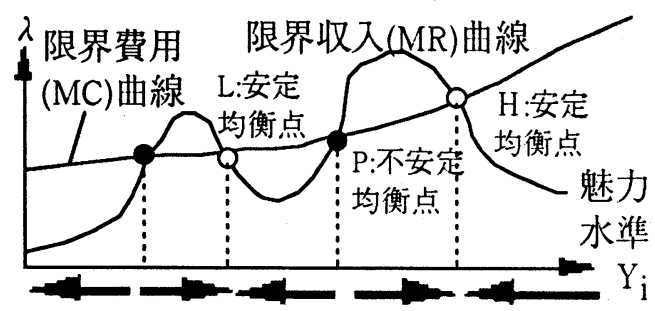

$\mathrm{Yi}(\mathrm{t})$ の長期的変化の方向

図ー1 最適更新による魅力水準の挙動

新行動の投資コストを表す Penrose 型費用関数であ り、投資効率の週隇 $C \geq 0, \partial C / \partial y>0, \partial^{2} C / \partial y^{2}>$ 0 を仮定する。また、一旦ある程度質の高い魅力が確 保できれば少額の投資でも魅力の向上がはかれると いう効果があると考え、 $\partial C / \partial Y \leq 0, \partial^{2} C / \partial Y^{2} \geq 0$ と仮定する。さらに簡単化のため $\partial^{2} C / \partial Y \partial y=0$ と する。

\section{（2）累積利潤}

魅力づくりに対する投資の効果は長期的に継続 することから、各小売店は各時点で (3) 式を評価す るのではなく、長期的な累積利潤 $\Pi_{i}$ を最大化するよ うに質的魅力 $Y_{i}$ に対する投資計画 $y_{i}$ を決定すると考 えられる。これは (1) 式を制約条件とし、次の (4) 式 を目的関数とする動学最適化問題として定式化でき る5)8)。ただし

$$
\Pi_{i}=\int_{0}^{\infty} \pi_{i}\left(Y_{i}(t), y_{i}(t), \widetilde{Y_{o}(t)}\right) \exp (-\rho t) d t
$$

\section{(3) 最適更新解の導出}

上記の動学最適化問題の解は最大原理5)6)を用い て導出できる。すなわち、ハミルトニアンを、

$$
\begin{aligned}
H=\{ & \left.f\left(Y_{i}\right) g\left(Y_{i}\right)-C\left(y_{i}, Y_{i}\right)\right\} \exp (-\rho t) \\
& +\mu\left(y_{i}-\gamma Y_{i}\right)
\end{aligned}
$$

と定義すれば、随伴方程式は、

$$
\frac{\mathrm{d} \mu}{\mathrm{d} t}=-\left(\frac{\partial(f g)}{\partial Y_{i}}-\frac{\partial C}{\partial Y_{i}}\right) \exp (-\rho t)+\mu \gamma
$$

となり、 $\lambda=\mu \exp (\rho t)=\partial C / \partial y_{i}$ と置くと、次に 示す式が得られる。これは変分法9)10)におけるオイ ラー方程式に他ならない。

$$
\frac{\partial(f g)}{\partial Y_{i}}=\frac{\partial C}{\partial Y_{i}}+(\gamma+\rho) \frac{\partial C}{\partial y_{i}}-\frac{\mathrm{d} y_{i}}{\mathrm{~d} t} \frac{\partial^{2} C}{\partial y_{i}^{2}}
$$

このオイラー方程式 (7) の左辺は魅力の増加に伴う 収入の增加量を表しており「限界収入 (MR)」、右 辺第 1、2 項の和は魅力の増加のためのコストを表 す「限界費用 $(\mathrm{MC}) 」 に$ 対応している。更新コスト の遁增を意味する右辺第 3 項があるため、均衡水準 $Y_{i}(t)=Y^{*}(t)$ に瞬時に調整する解は最適とならず、 逐次的な投資により漸近していく解が最適解となる ことが保証される5)7)。

長期的な均衡においては $Y_{i}(t) \approx Y^{*}$ となり $y_{i}(t)=\gamma Y^{*}$ も一定になるため、 $\mathrm{d} y_{i} / \mathrm{d} t=0$ と見な すことができ、第 3 項は無視できるので、

$$
\frac{\partial(f g)}{\partial Y^{*}}=\frac{\partial C}{\partial Y^{*}}+(\gamma+\rho) \frac{\partial C}{\partial y^{*}}
$$

が成立する。ただし $y^{*}=\gamma Y^{*}$ である。均衡解を図解 すると図ー1に示すように、左辺の限界収入 (MR) 曲線と右辺第 $1 、 2$ 項の和である限界費用 $(\mathrm{MC})$ 曲 線の交点として与えられる。

最適解の 2 階の条件式は任意の $C_{2}$ 級の関数 $z(t)$ に対して次式の第 2 変分が非正であればよい11)。

$$
J^{\prime \prime}=\int_{0}^{\infty}\left(\pi_{Y^{\prime} Y^{\prime}} z(t)^{2}+\pi_{y y} \dot{z}(t)^{2}\right) \exp (-\rho t) d t
$$

ただし、 $\pi_{Y Y}=\frac{\partial^{2} \pi}{\partial Y_{i}^{2}}, \pi_{y y}=\frac{\partial^{2} \pi}{\partial y_{i}^{2}}, \dot{z}(t)=\frac{\mathrm{d} z(t)}{\mathrm{d} t}$ であ る。費用関数に関する仮定 $\partial^{2} C / \partial y^{2}>0$ より $\pi_{y y}=$ $-\partial^{2} C / \partial y^{2}<0$ であるから、上式は $\pi_{Y Y} \leq 0$ であれ ば满足される。すなわち最適解の 2 階の条件は次式 に置き換えられる。

$$
\begin{aligned}
\pi_{Y Y^{\prime}} & =\frac{\partial}{\partial Y_{i}}\left(\frac{\partial(f g)}{\partial Y}-\frac{\partial C}{\partial Y}-(\gamma+\rho) \frac{\partial C}{\partial y}\right) \\
& \leq 0
\end{aligned}
$$

限界収入曲線が左上から限界費用曲線に交わる安定 均衡点ではこの条件が満足される。なお限界収入曲 線が左下から交わる点は不安定均衡点であり、最適 性は保証されない。

以上のことから初期值 $Y_{i}(t=0)$ から安定均衡点 に向かって $Y_{i}(t)$ が移動し収束するように投資する ことが最適投資経路 $y_{i}^{*}(t)$ となる。 $Y_{i}(t)$ の変化の方 向は初期值 $Y_{i}(t=0)$ がどの区間にあるかによって 異なる。すなわち初期值が不安定均衡点より大きく 安定均衡点より小さい場合には魅力を増大させる投 資が最適解となり、初期值が安定均衡点より大きく 不安定均衡点より小さければ更新を十分に行わず魅 力を減少させることが最適解となる。 


\section{(4) 限界収入曲線の概形}

オイラー式 (8) の左辺の限界収入は次のように 変形できる。

$$
\frac{\partial(f g)}{\partial Y_{i}}=f\left(Y_{i}, \widetilde{Y_{o}}\right) \frac{\partial g}{\partial Y_{i}}+\frac{\partial f}{\partial Y_{i}} g\left(Y_{i}, \widetilde{Y_{o}}\right)
$$

右辺第 1 項は自店の更新によって集客 1 人当たりの 売上げが高まることによる利潤の増加分を、第 2 項 は自店の更新によって集積全体の集客力が高まるこ とによる利潤の増加分を表している。いずれの効果 とも一定の投資水準を超えて顕著に現れ、やがてそ の効率は頭打ちになるため、 $Y_{i}$ に対して峰を持つ関 数となる。商業集積の規模に比べて自店の規模が小 さい場合には第 1 項の峰は比較的小さな $Y_{i}$ において 生じる。一方自店の更新のみで集積全体の集客力を 上げることは困難であり第 2 項の峰はかなり大きな $Y_{i}$ に位置する。よって (11) 式は一般に 2 つの峰を持 つ関数となる。

商業集積の規模が大きいほど、また他店の魅力 の水準が高いほど、関数 $f$ の值は大きく、関数 $g$ の值 は小さい。また、他店の質的魅力 $\widetilde{Y_{0}}$ が自らの更新行 動 $Y_{i}$ とどのように関連しているかにより、関数形は かなり異なったものとなる。

\section{a) 商業集積内の競争が激しくないケース}

集積内に同じ業種の商店が少ないなどの理由で 顧客獲得競争が激しくない場合、自店の魅力更新は 他店の魅力の水準に大きな影響を与えないであろう。 このとき (11) 式の第 2 項の効果はかなり大きな $Y_{i}$ に対して生じるので、限界収入曲線の 2 つの峰は離 れ、間の凹みも深いと考えられる。

\section{b) 商業集積内の競争が激しいケース}

同じ業種の商店が多数集積するなど、箱積内の 顧客獲得競争が激しい場合、一店の行動に他店が追 従し結果的に各店が同じような更新行動をとる傾向 が強いと考えられる。この場合、自店の魅力の水準 $Y_{i}$ への投資が他店の魅力更新行動 増幅されるため、(11) 式の第 2 項の峰が比較的小さ な $Y_{i}$ において生じる。一方自店の魅力度をかなり高 めない限り他の店舗との差が出せず集客 1 人当たり の利潤が伸びないことから、(11) 式の第 1 項の峰は 右へシフトする。結果として限界収入曲線の 2 つの 峰は接近し、間の凹みは小さいと考えら机る。

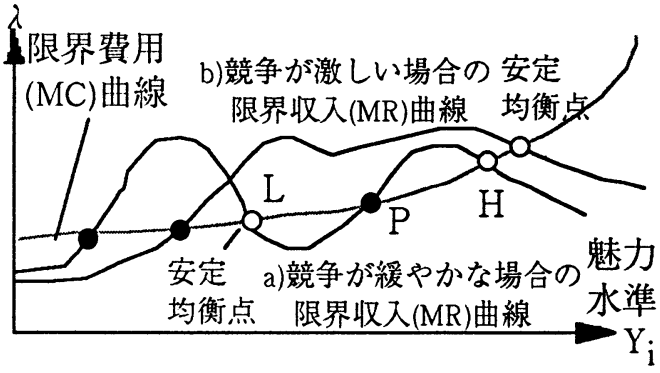

\section{図-2 集積内の競争と均衡点}

\section{（5）均衡点の位置と最適更新行動}

費用関数の仮定 $\partial^{2} C / \partial y^{2}>0, \partial^{2} C / \partial Y^{2} \geq 0$ よ り、限界貲用曲線は $Y_{i}$ に対して右上がりの曲線とな

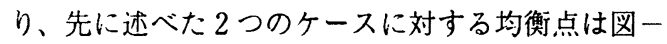
2の a)b)のようになる。すなわち、a) 集積内の競 争が激しくない場合には、2つの安定均衡点が存在 しうち 1 つは Y $Y_{i}$ の小い領域に位置する。そのため 低い方の安定均衡点 Lに向かうという低調な更新行 動が最適解になりやすい。b) 集積内の顧客獲得競争 が激しい場合には、均衡点が $Y_{i}$ の比較的大きな位置 に1つしか存在しない可能性が高く、その状況 Hに 向かって活発に更新行動を行うことが最適解になり やすい。

以上のことから商業集積内の競争が緩やかな場 合には魅力更新に関する投資が小さくなり、結果と して商業集皘全体の魅力の低下が起こりやすい。特 にもともと魅力度が低く、不安定均衡点 $\mathrm{P}$ の左側に 位置するような商店が大きな割合を占める商業集積 では、このような傾向が強く現れることがわかる。

\section{4. 商業集積における小売店のただ乗り}

\section{（1）他店による魅力の向上の予測}

競争が激しくないa) タイプの商業集積の内部に 新たに大規模店が進出を計画している場合を想定し よう。既存の小売店は大規模店の進出によって、商 業集積の質的魅力の水準 $\widetilde{Y_{o}}$ が増加すると予測するで あろう。このとき集積の集客力関数 $f$ は魅力の向上 を反映して時間とともに上方にシフトするが、自店 の相対的影響力の低下により右にシフトする。また 競争が激しくなることから利潤関数 $g$ は右下方にシ 
フトするため、限界収入曲線は図ー3のように右方 ヘシフトし、限界費用曲線が時間とともに変化しな いものとすれば、 2 つの安定均衡点 $\mathrm{L} 、 \mathrm{H}$ とその間 の不安定均衡点 $\mathrm{P}$ はすべて右方に移動する。

\section{（2）不活発な更新行動}

以上の変化は小売店の最適更新行動を变化させ る。もともとは初期値 $Y_{i}(t=0)$ が不安定均衡点 $\mathrm{P} よ$ りも右に位置し積極的に更新を行おうと考えていた小 売店の中に、点 $\mathrm{P}$ の右への移動にともない $Y_{i}(t=0)$ が点 $\mathrm{P}$ の左側に位置するようになり、積極的に更新 を行おうとしなくなる小売店が出現する可能性があ る。他店の魅力更新に対する期待が大きく限界収入 曲線のシフトが大きいほど、更新意欲を失う小売店 の割合は増加すると考えられる。

なお図ー2 から、競争が激しいb) タイプの㹍業 集積においては限界収入曲線の右方へのシフトが起 こっても均衡点の個数は変化しないことがわかる。 つまり大規模店の進出に伴う更新意欲の衰失という 問題は生じにくい。以上から、同業者の混在の割合 が低く小売店間の競争が緩やかな商業集積において、 もともと魅力が低い小売店が多ければ、新規に進出 する大規模店や他店の更新投資の効果に頼って自店 の更新投資を積極的に行わない消極的な小売店が增 加する。このような「ただ乗り」とも言うべき行動 をとる小売店が多く存在すると、その結果として集 積全体での魅力も低い水準に留まってしまうという 問題を引き起こす。

従来商店街の不活性の原因を論じる場合には、経 営者の高齢化、後継者の不足、資金調達能力の低さ など、各小売店が小規模、零細であるがゆえの制約 的な要因の指摘に留まっていた2)。確かにこ机らの 制約要因が最適投資を行うことを困難にし、商店街 の衰退を押し進めたことは否定できず、商店街組織 による共同事業や低利貸し付けなど、制約を緩和す るための方策が実行されている。しかし、上述のモ デルに基づけば、他店舗の更新へのただ乗りという 行動が各小売店の最適な更新行動である可能性があ る。更新行動が進まないという問題を解決するには、 個々の小売店の制約を緩和させるだけでは十分では なく、むしろ商店街の構造をただ乘りを生みにくい 構造へ転換して、既存小売店の魅力の更新が自発的

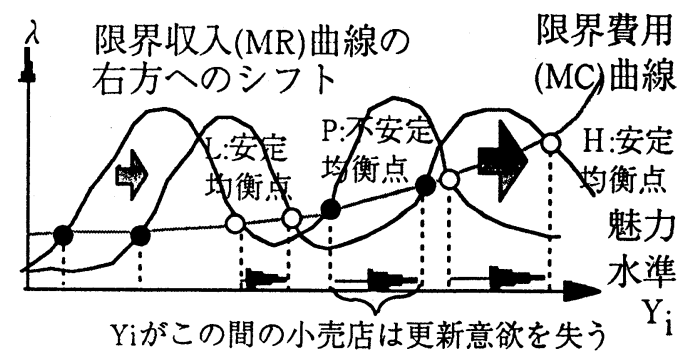

図一-3 他店による魅力更新による均衡点の変化

に行われるようにすることが重要となる。

\section{5. 商業集積における小売店の活性化策}

ここでは上述 のモデルを活用して、自治体や商 店街組織による商店街活性化策についての理論的な 考察を試みる。

\section{（1）魅力更新に対する公的補助金の効果}

各店舗が行う魅力更新投資に対して自治体や商 工組織が補助金を用意する政策を考える。まず各小 売店の更新投資に関わらず一定の額の補助金を与え る場合を考える。このとき各小売店の利膶関数に一 定値が加算されるだけであるので均衡条件式 (8) は 変化しない。よってこの政策により更新行動は影響 を受けないので上述した「ただ乗り」を防ぐ効果は 期待できない。

次にある期の質的魅力に対する投資額に比例し て補助金を与える政策を考える。この時限界費用曲 線が (1 一補助率) の割合で下方へシフトする結果、 2 つの安定均衡点はともに右に移動して均衡水準が 高まるとともに、不安定均衡点 $\mathrm{P} か ゙$ 左に移動し積極 的な更新行動をとる小売店を増加させることができ る。また補助率が大きければ、限界費用曲線が下方 へ大きくシフトし、小さい方の安定均衡点（L）を 消滅させて、すべての小売店に積極的な更新を促す ことができる。

補助率が小さく均衡点を右に移動させるだけの 政策では、長期間にわたって補助金を与え続けるこ とが前提となる。補助率を大きくして安定均衡点の 個数を変える政策は、店舗の魅力が不安定均衡点を 
越えて大きくなる時点で打ち切り、その後資金を回 収することが可能であり、効率的な政策であると考 えられる。ただしこの政策を実際に行うためには、 公共の資金を個々の店舗に与えることの妥当性の検 討、更新行動や魅力の水準を定量的に観察するモ二 タリング技術の開発が必要である。

\section{（2）小売店組合による補助金の効果}

次に小売店の組合が各小売店から一定額ずつ徽 収した財源を、質的魅力の投資額に比例して再配分 する政策を考える。まず各小売店から一定額を徵収 することにより利潤が小さくなるが、均衡条件式 (8) には影響を及ほさない。この財源を投資額に比例し て配分する段階で限界費用曲線が下方にシフトし、

(1) の政策と同様の効果が期待できる。

さらに、各店が徴収された財源からの罡付を競っ て獲得しようとして更新行動が競争的に行われるよ うになり、3.b)の競争的なケースに近づく。そのた め、限界収入曲線が図 2(b)に示される「ただ乘り」 の起こりにくい形へと変形することが期待できる。 各店から一定額の徴収を行うことに対する合意形成 ができるかどうかは問題であるが、効果の大きな政 策であると言える。

\section{（3）共通基盤の整備による効果}

アーケードの設置や改修、カラー舗装歩道の整 備、コミュニティー施設の建設など、商業集積の共 通基盤を整備することは以前から活性化の主要な手 段と考えられてきた。

これらの共通基盤の整備によって、各小売店は 集積全体の魅力が向上し、地区の集客力 $f$ が高まっ たと認識するであろう。こ机に伴い限界収入曲緗は 上方にシフトする。この結果不安定均衡点 (P) が 左に移動して積極的な更新行動をとる小売店が增加 する。さらに共通基盤の整備効果が十分に大きく限 界収入曲線のシフトが大きけ机ば、小さい方の安定 均衡点（L）を消滅させて、すべての小売店に積極 的な更新を促すことができる可能性がある。

ただし、各小売店の売り上げなどに比例する形 で財源を集めると、間接的に限界費用曲線を上力に シフトさせることになるため、この効果は打ち拈さ れてしまう。また、図ー2 から明らかなように、も
ともとの限界収入曲線の中央の凹みが染い場合には 均衡点の移動はほとんど期待できない。すなわち同 業者の混在の割合が低く小売店間の競争が緩やかな 商業集積においては、共通基盤の整備に小売店の更 新投資を積極的に行わせるという効果は期待できな い。これらのハードな施設整備に合わせて、(1)(2) のような政策を組み合わせることが重要である。

\section{（4）更新計画業務を補助する政策の効果}

個人経営等の零細な小売店が魅力更新を計画す る際に、消費者ニーズの把握や他店舗、他地域の情 報収集を外部機関に委託したり経営コンサルタント 等の指導を仰ぐことは、経費負担の面から困難であ ることが多い。そこで自治体からの補助金や小売店 組織の財源を活用して、各店の更新計画を補助する 政策が考えられる。実際、中小小売商業活性化推進 事業による助成金制度がこれに該当する3)。この政 策により、時点の将来利潤の予測に対する信頼性が 高まり割引率 $の$ 值を低く設定できる。あるいは的確 な見通しを持って更新を行なえば質的魅力の陳腐化

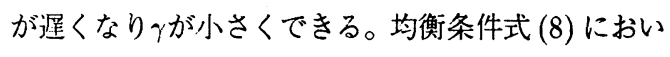
て限界嘖用曲線を引き下げるのと同様に、更新投資 を活発化させ、魅力の向上を早める効果がある。

\section{6. 数值計算例}

以下では具体的な関数形を特定化し、数值計算 により上記のモデルの妥当性を確認しておく。

\section{（1）利潤関数と費用関数の仮定}

いま、同規模の $n(=20)$ 個の小売店からなる商 業策積を考える。一定規模の市場に対して立地条件・ 規模の同等な $N=4$ 個の商業集積（質的魅力 $\bar{Y}=1$ ) との競争関係にあると仮定する。標準的なロジット モデルにより関数 $f$ 及び $g$ を以下のように仮定する。

$$
\begin{gathered}
f\left(Y_{i}, \widetilde{Y_{o}}\right)=\frac{1}{1+N \exp \left(\alpha\left(\bar{Y}-\widetilde{Y_{o}}\right)\right)} \\
g\left(Y_{i}, \widetilde{Y_{o}}\right)=\frac{1}{1+(n-1) \exp \left(\beta\left(\widetilde{Y_{o}}-Y_{i}\right)\right)}
\end{gathered}
$$

ただし $\alpha=3.0, \beta=1.5$ を仮定する。競争が激しい 場合、自店の投資が他店の魅力更新行動に影響する。

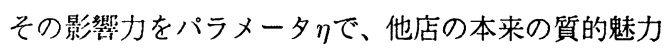




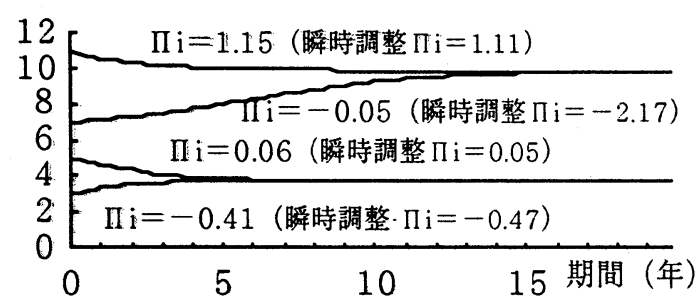

図一４異なる初期状態からの最適更新経路

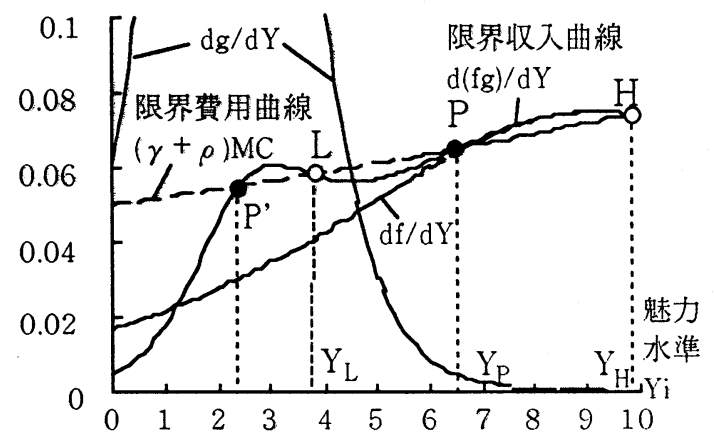

図ー5 基本ケースにおける限界収入と限界費用

の水準を $Y_{o}$ と表せば、集積の魅力度の予測值 $\widetilde{Y}_{o}$ は、

$$
\widetilde{Y_{o}}=(1-\eta) Y_{o}+\eta Y_{i}
$$

と表される。

一方、投資費用関数 $C(y, Y)$ は簡単のため、 $y_{i}(t)$ のみの次の関数を仮定する。

$$
C\left(Y_{i}(t), y_{i}(t)\right)=\exp \left(0.2 y_{i}(t)\right)-1
$$

\section{（2）基本ケース}

関数を差分化し計算期間を 20 年、計算問隔 0.25 年として最適経路を求めた。他店への影響力 $\eta=0.1$ 、 他店の魅力の水準 $Y_{o}=0.6$ 、陳腐化率 $\gamma=0.2$ 、割 引率 $\rho=0.05$ としている。使用ソフトは、SD 用シ ミュレーションソフト STELLA である。図ー4に は、 $Y_{i}(t=0)$ の種々の初期值に対する以降の魅力更 新経路を示している。収束解は $Y_{L}=3.76, Y_{H}=9.87$ である。図中には各ケースの長期利潤と、 $Y^{*}$ に最初 の 0.25 年で瞬時に調整した場合の長期利潤を比較し ている。これより瞬時の調整が最適ではないことが わかる。図一 5 には限界収入と限界费用曲線を示し

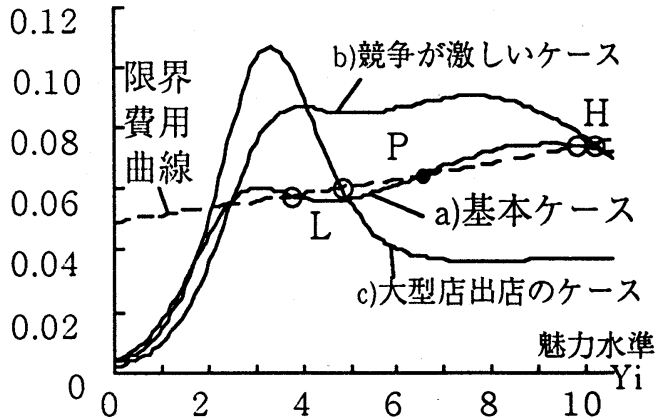

図-6 競争条件の違いと大型店進出の効果

ており、上述した収束解は両者の交点の均衡解であ ることがわかる。なお不安定均衡点は $Y_{P}=6.49$ と $Y_{P^{\prime}}=2.38$ である。

\section{（3）競争条件の違いと大型店進出の効果}

競争条件の違いにより限界収入曲線は異なる。上 述したa) 基本ケースに加えて、b) 競争が激しいケー スとして、当該集積に扔ける商店数が多く $(n=20)$ 、 当該店の影響力も大きい $(\eta=1.2)$ の場合を、c) 大 型店出店のヶースとして、小型店 10 店分の規模の 大型店が進出し $(n=20)$ 、集積の質的魅力水準 が高まり $\left(Y_{o}=1.0\right)$ 当該店の影響力は小さくなる $(\eta=0.05)$ 場合を設定して、限界収入曲線を比較し たものが図ー6である。これよりb)のケースでは均 衡点 $\mathrm{L} か ゙$ 消滅し、高い魅力度 $Y_{H}$ を目指して活発に更 新が行なわ机るのに対し、c)のケースでは均衡点 $\mathrm{H}$ が消減し、更新活動が低調になることが確認できる。

\section{(4) その他の政策の効果}

その他の政策に関しても数值計算により、均衡 点の位置の変化を求めた。結果を表一 1 に示す。そ れぞれ、前章で述べたような効果が期待できること がわかる。

\section{7. おわりに}

本研究では小売店の質的魅力の更新行動を比較 的簡単な仮定の下でモデル化し、商店街等の集積に お外る不活性の原因を小売店の「ただ乗り」により 説明した。また「ただ乗り」の発生を防いで商業集 
表ー1 各施策による均衡解の位置の比較

\begin{tabular}{|c|c|c|c|c|c|c|}
\hline & ケース & 設定内容 & $\begin{array}{l}\text { 不安定 } \\
\text { 点 Y P. }\end{array}$ & \begin{tabular}{|l|} 
均偗点 \\
YL \\
\end{tabular} & $\begin{array}{l}\text { 不安定 } \\
\text { 点 YP } \\
\end{array}$ & \begin{tabular}{|l} 
均衡点 \\
$\mathrm{YH}$ \\
\end{tabular} \\
\hline a & ベースケース & $\begin{array}{l}n=9, \quad \eta=0.1, \\
Y_{0}=0.6, \quad \rho=0.05 . \\
y=0.20\end{array}$ & 2.38 & 3.76 & 6.49 & 9.87 \\
\hline $\mathrm{b}$ & 竸争激しい & $\mathrm{n}=19, \eta=0.12$ & 2.49 & 消失 & 消失 & 10.13 \\
\hline c & 大型店進出 & $\begin{array}{l}n=19, \eta=0.05, \\
Y_{0}=1.0\end{array}$ & 2.07 & 4.82 & 消失 & 消失 \\
\hline $5(1)$ & 公的補助 & 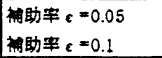 & $\begin{array}{l}2.26 \\
1.93\end{array}$ & $\begin{array}{l}4.3 \\
\text { 消失 }\end{array}$ & $\begin{array}{l}5.54 \\
\text { 消失 }\end{array}$ & $\begin{array}{l}10.51 \\
11.88\end{array}$ \\
\hline $5(2)$ & 租合補助 & $e=0.05, \eta=0.12$ & 2.04 & 消失 & 消失 & 10.42 \\
\hline $5(3)$ & 共通基盤整传 & $\begin{array}{l}Y_{0}=0.625 \\
Y_{0}=0.8\end{array}$ & $\begin{array}{l}2.24 \\
1.75 \\
\end{array}$ & $\begin{array}{l}4.28 \\
\text { 消失 }\end{array}$ & $\begin{array}{l}5.95 \\
\text { 消失 }\end{array}$ & $\begin{array}{l}9.79 \\
8.91 \\
\end{array}$ \\
\hline $5(4)$ & 計画集䅂補助 & $\begin{array}{l}\rho=0.04 \\
\gamma=0.15\end{array}$ & $\begin{array}{l}2.28 \\
1.98 \\
\end{array}$ & $\begin{array}{l}4.11 \\
\text { 消失 } \\
\end{array}$ & $\begin{array}{l}5.77 \\
\text { 消失 } \\
\end{array}$ & $\begin{array}{l}10.39 \\
11.85 \\
\end{array}$ \\
\hline
\end{tabular}

積を活性化させる方策について検討した。特にこれ まで活性化のための主要な手段とされてきた共通基 盤の整備は、ただ乗りの回避という点では効果を持 たず、他の政策と組み合わせることが重要であるこ とを明らかにした。

理論的に見れば、本研究は均衡解の比較静学的 分析にとどまっており、動学的な枠組みを十分に活 かしていない。特に Penrose 効果 $(\partial C / \partial Y \leq 0)$ は 商店間の動学的競争にとって重要な役割を果たすと 考えられる。微分ゲームへの発展など今後の検討課 題としたい。このほか、（1）質的な魅力更新行動と、 本モデルで所与とした立地場所や量的な鬼力变数の 決定行動を組み合わせた理論モデルの構筑、（2）商 店主の意向調查と連動させた実証的な分析を行う必 要があると考えている。
なお、匿名の査読者からは本論文に対して有用 なコメントをいただき、既存の投資理論との関保を 整理するのに大いに役立った。感謝の意を表する次 第です。

\section{参考文献}

1）細井助博：商店街・大型店と共存の道を、日本経洛新 聞経润教室 (7月 14 日)、日本経悯新聞社、1995

2) 石井淳嵗、石原武政; 街づくりのマーケティンク、日 本経润新聞社、1992

3) 水谷勝；商店街の活性化戦略、同文館、1989

4）文世一、小林溼司、吉川和広；商業地再開発の規模と 構成に関するモデル分析手法、土木学会論文集、第 401 号、pp69 78、1989

5) A.Takayama; Mathematical Economics, Cambridge Press, 1985

6) 朱保華：投資関数の理論、九州大学出版会、1995

i) R.Eisner, and R. Strotz; Determinant of Business Investment, in D.B.Suits et al eds., Impacts of Monetary Policy, Prentice-Hall, 1963

8) 西村清彦; 経済学のための最適化理論入門、東京大学 出版会、 1990

9) D.G. ルーエンバーガー; 動的システム入門、ホルト. サウダース・ジャバン、1985

10）近藤次郎：最通化法、コロナ社、1984

11）坂和愛幸：最適化と最通制御、森北出版、1980

小規模小売店の最適更新行動に関する研究

奥村 誠・松村慧一 近年、衰退している商店街が多い中で、小売店の更新を行い魅力を維持することに成功している商店街が 散見される。本研究では商業集皘における小売店の䰠力更新行動を動学最適化問題としてモデル化し、多 くの商店街で魅力更新が進まない理由を考察するとともに、更新を進めるための活性化方策について検討 する。具体的には、小売店の更新行動を長期累皘利潤の最適化行動によりモデル化し、競争が激しくない 商業集積では大型小売店の進出に賴って自力更新を行わなくなるという行動が起こることを指摘した。さ らに本モデルを用いて、商業集皘単位で行わ机ている活性化施策について、自力更新を活発化させるか否 かという視点から考察を加えた。

\section{Optimal Renewal Behavior of Small-scale Retail Shops}

Makoto OKUMURA and Ken-ichi MATSUMURA

Renewal of small-scale shops provides long-range competitive force to commercial districts. This paper presents an optimal renewal model of a retail shop utilizing dynamic optimization technique. The model clarifies the free-ride mechanism that each shop in a commercial district expects other shops' contribution and grudge its own renewal effort. Some policies to get rid of the free-ride motivation are discussed. 